\title{
Digital Games and Learning Mathematics: Student, Teacher and Parent Perspectives
}

\author{
Su Ting Yong ${ }^{1}$, Peter Gates ${ }^{2}$, lan Harrison ${ }^{2}$ \\ ${ }^{1}$ The University of Nottingham Malaysia Campus, Su-Ting.Yong@nottingham.edu.my \\ ${ }^{2}$ The University of Nottingham, \{Peter.Gates, lan.Harrison\}@nottingham.ac.uk
}

\begin{abstract}
The purpose of this study was to explore the potential use of digital games in learning mathematics at secondary school level in Malaysia. Three secondary school students, three mathematics teachers and three parents were interviewed in this study. All the participants were asked for their views and experiences in mathematics, technology usage and the use of digital games in learning mathematics. The results suggested that students were supportive and positive towards the use of computer games in learning mathematics. Nevertheless, parents preferred conventional teaching approach, in which they recognized personal communication and socialization as a significant component in learning. Although the teachers did not go on to oppose the idea of using computer games for teaching mathematics, they still perceived the use of discursive approaches as the best teaching approach for learning mathematics with digital technologies at best a possible additional complementary feature. In view of that, the combination of classroom teaching and computer games might the best mathematics pedagogy.
\end{abstract}

Keywords: mathematics, digital games, motivation, attitude, digital native;

\section{Introduction}

Mathematics is a backbone of many disciplines such as engineering, science, business and computer science. Success in mathematics is not only required a development of cognitive and metacognitive skills, but also depends on the affective domain [1]-[3], which is conceptualized by belief, attitude and emotion [4]. Other similar terms - "motivation", "disposition" and "will" have been interchangeably used in some literature [5], but the focus of this study was to investigate the affective domain.

Research has indicated that students' attitude towards mathematics learning with technology is greatly influenced by their attitude towards the subject itself and technology in general. For instance, students are more likely to have a positive attitude towards the use of computers in learning mathematics if they rated themselves highly in computer proficiency [6] and achieved good performance in mathematics [7]. Hence, the study of belief, attitude and emotion towards mathematics learning with digital games should also include the investigation on mathematics and technology usage.

The purpose of this study was to explore the potential use of digital games in learning mathematics at secondary schools level in Malaysia. The aims of the study were to explore students', teachers' and parents' views in:

- mathematics education

- technology usage

- use of digital games in learning mathematics 


\section{Literature Review}

\subsection{Belief and Attitude towards Mathematics}

Students' feelings and beliefs towards mathematics are important determinants to reinforce or weaken their mathematics performance [3], [8]. Students' motivation to learn mathematics is built based on their interest, self-efficacy and attributions [3]. In fact, students' attitude towards mathematics are influenced by their parents, teachers, teacher's teaching method, peer groups, society, level of self-confidence, motivation, previous experiences and teacher evaluation results [9]. Hence, apart from the students' personal interest and self-efficacy, teachers and parents play an important role in supporting and motivating students by giving them an appropriate positive reinforcement such as compliment and recognition. In school, teachers play a significant role and having a great influence on a child's development. Teachers' attitude, enthusiasm, support and confidence given to the students are the most significant factors influencing students' attitude towards mathematics [10]. A good teacher may change students' negative attitude towards mathematics to positive experience [11].

Other than interest, self-efficacy and attributions highlighted by Mayer [3], another important motivation factor is usefulness. Students' attitude towards mathematics is influenced by how students think about the usefulness of mathematics in daily life [10]. Mathematics is important and useful but students rarely see the usefulness of mathematics.

"...we often erroneously presuppose that we have engaged the student's learning commitment. But the student rarely sees significance in the learning...The learning is meant to deal not with the student's problem.... but with someone else's" [12, p. 101].

Some students do not appreciate mathematics learning because they could not find meaningful applications of mathematics in their daily lives, for instance how calculus is used in engineering and finance; and how probability is used in actuary sciences, lucky draw and gambling. To motivate students in mathematics learning, many efforts and innovations have been put forward in recent years by integrating digital technology such as video or computer games into mathematics education e.g. [13]-[15]. Game-based learning was found to produce positive affective learning outcome such as self-efficacy and continuing motivation [2]. Nevertheless, successful implementation of game-based learning requires a positive attitude and support from the students, teachers and parents.

\subsection{Learning with Educational Games}

Educational games are motivationally driven as the learning content can be merged into the motivating games to create a motivating learning environment [16]. Many studies have revealed that students were positive towards use of educational games in learning and they normally describe educational games as motivating [17]-[22], fun [18], [20], [23] and help to understand complex subject [22]. From the students' point of view, they may want to have something fun that enabled them to play and learn at the same time. However, teachers may view it from a different perspective.

Albeit all the positive impacts of educational games on learning, it is a fact that some issues raised in adopting the technology need to be delivered. The educational games may not be appealing to all students and they may not learn because distracted by the gameplay [1]. Furthermore, the educational games that enable learning may affect the nature of a game [1]. According to a study conducted by Becker [24], teachers were generally concerned about the feasibility and practicality of educational games use for learning. In Becker's study, the teachers argued that they were burdened with a heavy workload, with no time to learn new technologies, low computer proficiency, lack of confidence and knew of no suitable game that could be used to teach effectively and even they found one, they may not know how to use it. The use of games in learning is not feasible if teachers are not confident and positive about it. In fact, teachers' acceptance on educational games was also influenced by students' attitude towards use of educational games in learning [19]. Whilst a lot of research has been done on digital game-based learning, teachers were not inclined to find time to read those research finding in order to apply those latest effective approach into their teaching [24]. Obviously, there may be a gap between the two generations; students who are positive towards use of educational games in learning; and teachers who are more conservative and reserved in trying out new ideas and innovations in their 
teaching. Some mathematics teachers may be resistant to change as they believe that there is no possibility of using technology in teaching due to a large number of learning objectives to cover [25]. A further study in Australia by Zevenbergen also revealed that senior people (i.e. older than 22 years old) tended to perceive mental computation and basic mathematics skills such as addition, multiplication and subtraction as essential skills for work practices, but young people (i.e. 22 years old or less) were more reliant on the technology to undertake such computations [26]. Such differences in perceptions between the senior and the young generation were also highlighted in Prensky [27]. According to Prensky [27], digital immigrant teachers always think that their current teaching approach is the only way to teach and that learning should not necessarily be designed as fun. However, digital native students think and process information differently from their digital immigrant teachers as they have grown up surrounded by and using technologies [27].

In recent years, the Malaysian Ministry of Education has introduced various information technology initiatives (e.g. use of courseware, PowerPoint) into the teaching and learning at secondary schools level, especially for science and mathematics. The initiative of digitizing education has been contextualized within several national initiatives over the last 40 years [28]. However, educational games have not been formally used for teaching and learning of mathematics at secondary schools level. Thus, it is worthwhile to explore Malaysian students', teachers' and parents' views for potential use of digital games in learning mathematics. Though some earlier studies have been conducted in Malaysia [29], [30], most were related to quantitative data or game development and there is lack of qualitative research such as through in-depth personal interviewing. Furthermore, as technologies change rapidly, so does the mind-set of people. Therefore, it would be meaningful to understand what students, teachers and parents think about the use of digital games in mathematics learning in today's changing education system.

\section{Methodology}

This was a qualitative study that involved interviews with students, teachers and parents in exploring their views and opinions about mathematics and the use of technology in mathematics education. Qualitative research can provide in depth and rich information about participants' worldviews and their personal meanings, but its findings may not be readily generalized beyond the local research participants because the research is typically based on small non-random sample [31].

\subsection{Participants}

Qualitative interviews with students, teachers and parents were selected based on purposive sampling. In fact, almost all qualitative research uses purposive sampling because random sampling normally is usually not feasible [32]. In purposive sampling, "the researcher specifies the characteristics of the population of interest and locates individuals with those characteristics" [31, p. 239] and "select a sample they feel will yield the best understanding of what they are studying" [32, p. 439]. To understand mathematics education and use of technology in mathematics education, the most appropriate sample groups would be the students, mathematics teachers and parents because they have the direct or indirect exposure to the mathematics education system in schools.

In this study, three participants were recruited from each sample group, thus in total nine participants were interviewed. In qualitative research, sample size also does not follow any specific rule, and there is no exact sample size that is considered as appropriate or representative [33]-[37] because the sample size depends on the purpose of research, what is useful and what can be done given the available resources [35], [36]. This was a phenomenological piece of research that studied an individual's experience and perceptions. For such research, the recommended sample size is at least six participants [38], [39]; five to 25 participants [40]; six to 10 participants [37]. In fact, sample size in qualitative research should not be too small to make it difficult to obtain saturation and not too large to make it difficult to conduct a deep analysis [41]. If the amount of data required from each participant is rich and experiential (e.g. phenomenological study), then fewer participants will be required to reach saturation [37].

Nine participants in this study were chosen based on a maximum variation sampling. Three secondary students aged between 14 to 16 years old, whom ethnicities were Malay, Chinese and Indian, each from three different primary school backgrounds - Chinese vernacular school, Tamil vernacular school and national (Malay) school; three parents aged between 38 to 42 years old, 
whom ethnicities are Malay, Chinese and Indian - a PhD candidate, a clerk and a physicist; three teachers with 11 to 24 years of teaching experience, teaching at - lower secondary (From 1 to From 3), higher secondary (Form 4 to Form 5) and pre-university level (Form 6).

Though the sample size of nine could not be considered representative of the population, information on demographic and other characteristics of the sample studied have been included so that this study could be replicated with a similar sample in future to verify the results obtained were not a one-time occurrence. Moreover, some qualitative researchers e.g. [42], [43] have used small sample size as little as four. A review of the literature (i.e. 500 thousand doctorate dissertations) by [44] has revealed that all of the phenomenological studies had at least six participants, and $68 \%$ had five to 25 participants. Given the above arguments, the use of small sample in a phenomenological study is strongly justifiable.

\title{
4.2 Interview Questions
}

There were three sets of interview questions for students, teachers and parents asking for views and experiences in mathematics, computer, cell phone/ mobile phone, technological skill, gaming and educational computer game. Each interview lasted for approximately 1 hour. All the interviews were voice recorded with a permission sought from all the participants prior to the interview sessions. Though the interviews were conducted in English, some participants communicated in Mandarin or Malay because they felt more comfortable speaking in their mother tongue. For this reason, interviews were initially conducted in English, but when participants asked for further clarification using their mother tongue, further explanation would be given in their mother tongue too.

The interview questions were structured in eight major themes:

1. Demographic information - respondents' background (e.g. age).

2. Mathematics learning - students' attitudes towards mathematics and issues related to teaching and learning of mathematics.

3. Technology skill - proficiency and perception towards computer technologies.

4. Educational computer games - perceptions towards the use of computer games to learn mathematics.

Some of the interesting findings are discussed in the following section.

\section{Results and Discussion}

Data collected from the interview sessions was analyzed and three major themes were identified: mathematics learning, mathematics teaching and technology usage. The actual names of the respondents were excluded and being replaced by pseudonym. It is an ethical responsibility to protect the privacy of respondents and to assure confidentiality.

\subsection{Mathematics Learning}

\subsubsection{Students dislike mathematics}

All teachers interviewed claimed that students generally disliked mathematics. Two of the teachers said,

\begin{abstract}
"Generally, students do not view mathematics as an important subject. Many students just study mathematics for the sake of studying and for the sake of exam. They don't see how mathematics can be applied in their daily life." (Teacher V)
\end{abstract}

"Most of the students do not like maths. For better students, when they were in form 1, form 2 and form 3, when maths is straight forward and simple, they said they are very interested. When they come to form 4 and form 5 and the concepts are harder and they have to think further, and more and more difficult, they will say they don't like maths anymore. They can score well, but they don't really like it." (Teacher T) 
In view of that, a parent also mentioned that her children loved mathematics when it was easy and they disliked mathematics when it was difficult. When we interviewed student $\mathrm{S}$ who was currently in Form 4, she said she loved mathematics when she was in Form 1 to Form 3 because she could score high marks. Now, she disliked mathematics because it was difficult and she failed all mathematics exams.

Looking from a different perspective, the teachers felt that they were unable to capture the interest of their students in mathematics. Students who were not interested in mathematics would not work hard and refused to dig deeper to solve the mathematics problems [3]. Students generally just use drill-and-practice to achieve good results. This group of students can be classified as performance achievement oriented learners, in which they only learn what is needed to achieve good performance [45]. Students may not be to blame for this conception if schools are examoriented and most of the parents are highly concerned about grades.

This finding also supports the past literature in which as the students' progress to higher grades, mathematics becomes more abstract and difficult and their attitude toward mathematics tend to be more negative due to their perceived difficulty in the topics learned [46], [47]. Students will lose interest in mathematics if they do not have confidence and perceive themselves as lacking in capability to solve mathematics problems successfully. Students' motivation to learn mathematics is influenced by their perceived capability and self-efficiency in mathematics problem solving [3]. When students have perceived mathematics as a difficult subject, they will perceive that they could not do well.

\subsubsection{Students are weak in mathematics}

When the teachers were asked, "Recently there has been general opinion that students are falling behind in mathematics. What do you think about this?" all teachers had agreed to this statement.

"Yes, I agree with this view. I can see in my class as well. Students' performance is generally dropped for every batch of students. Generally, their skills and knowledge are poorer than the previous year...My students have a simple and naïve way to solve mathematics problems. That is how they have been taught in the school." (Teacher V)

"I totally agree with you. I think students are weak in all subjects. In the past, there was no Internet. Nowadays, students are blessed with easy life. Technology is moving too fast and students are always on the Internet. Thus, they have no motivation to study in the class because they can access to various information on the Internet. Or perhaps our teaching method is outdated...My students are extremely weak in mathematics, only one or two hardworking students in my class. They are weak in basic mathematics and they can't even master the multiplication table." (Teacher W)

"It is very true. Partly because of reduced content of teaching syllabus and examination standard. Parents and teachers are focused to teach students to pass well. A lot of drillings are done so that they know how to do the questions or methods in examination pattern...Students are not motivated to think as long as they can get the answer...My students can 't even do simple addition, subtraction, multiplication and division...The policy is teaching science and mathematics in English, but not all students are proficient in English. A lot of teachers are not efficient in English, so they are not using English to teach." (Teacher T)

In this section, the teachers have revealed a few common issues in mathematics education (a) poor basic numeracy skills (e.g. can't even do simple addition, subtraction, multiplication and division); (b) lack of metacognitive skills (e.g. simple and naïve way to solve mathematics problems); (c) learning for the sake of exams (e.g. not motivated to think as long as they can get the answer); (d) digital native students (e.g. no motivation to study - are always on the Internet).

The teachers have placed a strong emphasis on students' basic numeracy and metacognitive skills. This finding is supported by [26] that many teachers are still emphasizing the importance of basic computation, and by [3] that metacognitive skills are required to solve non-routine 
mathematics problems. Though students are claimed to have weak mathematical skills, students are not solely to be blamed. The learning environment itself has basically changed and many mathematics computations that previously required tedious manual computation can now be calculated using spreadsheets or a scientific calculator in a few seconds with a few clicks or button presses.

The teachers are also aware of the external factors such as the impact of technology advancement and the enforcement of policy at national level. The reduced content syllabus and low standard of examination success at national level in Malaysia have weakened the countries' performance in international comparisons as portrayed in TIMSS [48] and PISA [49]. Unfortunately, many were not aware that Malaysia had suffered a decline. For instance, all the parents interviewed in this study looked puzzled or said "I don't know about this" when the same question was asked.

Looking from the students' point of view, that they are weak in mathematics may be due to their disinterest in mathematics. Negative attitudes towards mathematics may cause a failure to learn appropriate mathematical skills [9], [47]. Furthermore, low proficiency in the language of communication (e.g. English) would give some negative impact on the quality of teaching and learning.

\subsection{Mathematics Teaching}

\subsubsection{Teachers use different ways to motivate students}

When the teachers were asked the question "how do you motivate your students to learn, do you use any tricks to make the lesson easier and fun for the students?" they have given some interesting responses. For example:

"My students always come to class without pen or pencil. So, I will conduct questions and answering sessions, and give pencil, pen and ruler as rewards. But, most of the time, they will lose all the stationaries on the next day. So it is quite useless." (Teacher W)

"I will use colour chalk to show different steps and different things. I try to help students to remember certain thing. Remember teaching the quadrant - all, sine, tangent and cosine (or kosinus in Malay language). Asking students to memorize all quadrants is very difficult. I grew up in Sibu, so they say 'all sibu tauke'. When I come to here, the teacher said 'add sugar to coffee'. It is very easy to remember. Then one of my students said 'all science teachers crazy". These are the things to make the lesson interesting. I also use all my body, my hand and my hair. If I can help them, I don't mind. I remember one topic when I teach straight line. They can't remember what is vertical and horizontal line? So I have to use my hand. My student said Ultraman and they laugh." (Teacher T)

In this section, the teachers have explained how they use different approaches to make the lessons more fun and interesting for students to learn. It can be seen that teachers here report the students are not internally motivated to learn mathematics and the teachers have been trying their best to gain their interest. This group of students are dependent learners that rely on external motivation for learning [50], [51]. Motivation is an important affective component in mathematics learning. Motivation creates a strong participation in learning, thus satisfying innate needs increases efficient learning [50].

\subsubsection{Chalk-and-talk is the best teaching method}

Generally, all the mathematics teachers reported they were using a form of a "chalk-and-talk" exposition/explanation method because they felt that it was the best teaching method for mathematics. Digital immigrant teachers normally perceive their teaching approach as the only way to teach [27]. However, they did report that they did utilize group discussions and the use of computers in teaching, albeit irregularly. Teacher $\mathrm{T}$ and teacher $\mathrm{W}$ claimed that the use computer in teaching was not effective. 
"Most of the time I use chalk and talk. But I encourage students to use collaborative methods among themselves so that they can ask each other question and they can brainstorm among themselves. If the topics I teach use a lot of diagrams, shapes and spaces, I may use PowerPoint or Geometer's Sketchpad to show how changes take place with animations. But for straightforward topic like algebra, I just use chalk and talk...Tell you the truth, whenever we let students learn using technologies like computer, they will find it very fun. Somehow it is zero effective. The students just want to have something fun." (Teacher T)

"I mostly use chalk and talk. I seldom use group discussion. I did use teaching aids but it was in the past. I seldom use the mathematics courseware provided by the Malaysian Ministry of Education because I think it is useless and not effective at all. I think chalk and talk is still the most effective method." (Teacher W)

Arguments made by teacher W and teacher T coincided with a study [52] in which it was found that the use of computer technologies can motivate students to learn mathematics but it may not improve their cognitive skills. Even though all three teachers did use computer technologies in teaching in some way, they still preferred traditional chalk-and-talk methods, which they claimed to be the best instruction method. One of the students claimed that he was unhappy with his teacher's teaching approach.

"Actually my maths teacher just talks and gives us exercise. In school, we are not learning actually. The teachers just talk...talk and give us homework. May be just a shame for them. My teachers always late for 20 minutes to class. I swear. When I ask question, teacher just ask me to sit down. He just gives us homework a lot." (Student N)

Apparently, the traditional chalk-and-talk teaching method, drilling exercise and passive learning were not favored by student $\mathrm{N}$. He even claimed that he did not learn anything at school. In fact, this is a serious problem that should be looked into seriously. Although we have no evidence of learning, we do here have evidence of a clash of perception. From the digital native students' point of view, their digital immigrant teachers are the ones making the education not worth paying attention to [27].

\subsection{Technology Usage}

\subsubsection{Parents focus on interpersonal communication instead of on computer}

From the parents' interviews, it was found that all of them do not support being fully reliant on computer games or technology for learning. In their opinion, computer technologies can only serve as supplement or as a support to traditional classroom teaching. For the parents, education is not about learning something using technology. What they feel more important for child development is the interpersonal or social communication between the teacher and the students. It is very interesting to observe the parents' conservative views against current thinking within education. For example:

"For TV, only children educational programme less than one hour per day is allowed. More than that, it will destroy the child's development for sure. TV is only important for language and nothing else. But, you must sit together with them, watch together and you talk, then it will be useful. But if you are not there and let them watch for hours, then it is useless. For computer - totally no. I don't think they need computer. They need more social interaction. I am very strict. Even if my children use my iPad, only 30 minutes and I will sit together with them." (Parent R)

"I won't object the school to teach computer to my child, but I won't take the initiative to teach him computer. I think learn typing is okay, but not game. I don't support the use of animation or games 
for teaching. A good teacher should spend more time communicate with the students, but not through the computer. The problem with education nowadays is the lack of communication between students and teacher. If teacher spend more time with the students to answer their queries, many students will perform well." (Parent T)

Apparently, parent $\mathrm{R}$ and parent $\mathrm{T}$ have their conservative views toward education but they do have their respective rationale for their child upbringing. Indirectly, they may view their teenage child as not matured and that they are vulnerable in thinking and behavior. Teenagers are more likely than adults to use computer and they might form "electronic friendships" with the computer, instead of real friendships with humans being, deterring the real life interpersonal skills [53]. Some experts raised their concern of teenagers who spend so much time interacting on social network and mobile phones might fail to develop the essential social communication skills and being less confident in the intra-personal interactions [54]. Being educated parents, they seemed to be aware of this problem. Parents play a major role in controlling the children's access to a computer and the Internet, to make sure that they do not misuse the technologies. Past research has also indicated that socio-economically advantaged students are unlikely to access online games due to more strict parental supervision [55].

Parents may have their conservative views towards education with the fact that teenagers are still in the process of development. The children need proper guidance in differentiating between the good and the bad because parents have more life experience, wisdom and knowledge that children do not have. Their perceptions and ways of upbringing the children are not an unusual practice in the conservative Asian culture. In Asian families, parents and elders wield greater authority, and the parenting role has been labelled as excessively strict [56].

The parents also believed that digital technology is the cause of anti-social behavior in children. However, it is argued that teenagers who spend a lot of time on a computer or the Internet are not "addicted to the technology", but they are engaged with their friends [57]. Similarly, teenagers who constantly communicate online (e.g. email, Facebook, Skype, etc.) are not antisocial, but rather they are preparing themselves with the essential communication skills required for their future adulthood at work [57] - a future which will be potentially very different to the present day in which adults live. In fact, a study conducted in Malaysia showed that playing computer games at school could actually develop social communication skills among the students [30].

\subsubsection{Children love everything on computer}

One interesting point given by parent $\mathrm{S}$, she said:

"My children only use computer for fun and they think computer is only used for entertainment because they never used computer at school. My first son, when I asked him to do fraction, if he doesn't know how to do, he will google it and watch the YouTube. If you just write on the paper, he is not interested. My third child, he has bored with his ABC book. Computer is very important. Sometimes, I will switch on the computer and teach them on the computer. They will be excited."

In fact, all the teachers and parents agreed that students/children love computer and they were only good at using computer for entertainment - Facebook, YouTube, Twitter, Instagram, digital games etc. However, the students/children might not be good in searching for academic information and using the application software such as word processor and spreadsheet. This was an interesting contrast - when the students were asked a similar question, student $\mathrm{N}$ and student $\mathrm{V}$ gave a dissimilar view.

"I think I'm good in everything about computer but I'm weak in finding document on the Internet. Young teachers are equally good as me. Old teacher, I am better." (Student N)

"Some teachers are better. Some teachers are bad. My maths teacher, science teacher and computer teacher, they all are still bachelors, not married yet, between 25 and 35. So, they are better than me. But my Tamil teacher is old, more than 40. She is not good." (Student V) 
The students mentioned that young teachers were proficient in Information Communications Technology (ICT) and were more knowledgeable than the students. In contrast, old teachers were not proficient in ICT and were less knowledgeable than the students. Due to curiosity, we asked further - who are the old teachers? And who are the young teachers? The students have a similar justification in which, teachers in their 20s and 30s are considered young; teachers above 40 years old are considered old. Student V even mentioned that she justified this based on the types of mobile phone used by the teachers:

"My maths teacher, science teacher and computer teacher are so into social media and always with their phone. They use smartphone, so they are young teacher. Okay la... I think they are better than me in computer. My Tamil teacher is not like that. She has kids. She doesn't into social media and her phone also button phone. She is just like my dad. She is old." (Student V)

When clarified further with student $\mathrm{V}$, she said she perceived teachers who used smartphone were young teachers and those who used normal cell phone were old teachers. It is very interesting to see different logical thinking approaches used by adult parents and teachers versus teenage students. Adults make an assumption and justify their claims based on what they see and observe of the teenage students in their daily activities. All of the teachers and parents interviewed had the same idea that students were mostly good at using computers for entertainment. But when it came to the use of computers for academic or work purposes such as searching for information and the use of Excel and PowerPoint, students may not actually be able to use the software properly. A study conducted in Hong Kong showed that students had better technological skills related to social features, entertainment and advanced web or mobile features, whereas teachers had better technological skills related to work and simple web or computer functions such as use of search engine, online dictionaries, e-journal and creating presentation [58]. The teachers in their study also reported possessing more expensive and sophisticated technology devices [58].

Students have a simpler logic, in which they justify teachers' proficiency with computer as being based on their age and the mobile phone they used. The present study seemed to show a gap between students' and teachers' actual technological skills as perceived by each of the group. If mathematics computer games are to be introduced for classroom learning, teachers may underestimate students' capability in using the computers, and learning from their engagement with a perception that students are only good at technological skills related to entertainment. Similarly, students may also underestimate teachers' expertise in using computers, having a perception that old teachers are outdated. Those perceptions could be true, but both students and teachers may not aware of their own weaknesses. Consequently, introducing mathematics computer games for classroom teaching is a great challenge as both students and teachers are not prepared and equipped with essential technological skills.

\subsubsection{Positive view on usage of mathematics computer games}

From the interviews, we found that students were excited and positive about the idea of using computer games to learn mathematics in the classroom. However, when they were asked, "Could you name a few educational computer games that you know?", all the students seemed to be unfamiliar and not actively engaged with educational games.

"I don't know" (Student S)

“Pokemon..." (Student N)

"If I type maths game in Google, I can find" (Student V)

It is not surprising that students are not familiar with educational computer games because they have limited access to a computer. For instance, student $S$ had access to a computer once a week and for student $\mathrm{N}$ and $\mathrm{V}$, they had access to computer 2 to 3 times per month. This is not surprising due to strict parental supervision and all their parents are highly educated (i.e. at least with a bachelor degree). When the students were asked, "Would you recommend the use of computer games to learn mathematics in the school? " they said:

"Definitely yes. I think is good. It will make us more interested in learning because some of my friends are weak and have no intention to learn. But using games the students will get interested" (Student N) 
"Yes, I think students will pay more attention. They will like it. For me ah.... if I need to study maths during afternoon time, I never study. Cannot enter my brain. May be for afternoon session, people normally have problem. Game is better because computer room got aircon." (Student V)

The students' response to game-based learning was positive. However, the teachers and parents had a contradictory view. They mentioned that computer games could only serve as supporting learning objects. Teachers mentioned that traditional classroom teaching was still necessary because they believed that not all topics in mathematics can be taught using computer games, for example calculus integration and exponential functions. However, they are skeptical with the idea of using a computer game for mathematics teaching due to a lack of facilities and computers in the schools.

Students focus on their affective aspect towards learning in which how they feel, whether it is fun or boring. Conversely, teachers and parents focus on the feasibility and effectiveness of learning with mathematics computer game, but they do not view learning as something that should be fun. According to Thiagarajan as cited in [59], many people are resistant to making learning fun because for them, learning should be a painful experience. For the teachers and parents, they focus more on the importance of cognitive and metacognitive development in mathematics problem solving rather than the affective aspect and hence see the two as disconnected. However, much research on mathematical problem solving sees the two as interconnected domains.

\subsubsection{Modern technologies distract students' concentration}

Parent T pointed out an interesting point on "concentration". When he was asked the question "In digital games, do you think you learn concentration skill?" He said:

"Games cause more distraction than concentration. No doubt that playing games requires concentration, but actually kids are attracted to the animated and dynamic displays. For kids who play games, if you ask them to read a book, they hardly can sit down and concentrate because the book is static. Kids are only attracted to something for five seconds and if the thing doesn't change after five seconds, they won't concentrate anymore. That is why in daily life, these kids are very impatient and can't wait for someone even for few minutes. Actually their brain and psychology are disturbed and they have no peace of mind. I don't encourage children to watch TV or play games at all."

This is an interesting idea. An earlier study in Malaysia reported that students who spent more time on digital technologies were more vulnerable to psychological disturbances [60]. Other research also indicated that multitasking with digital technologies could be harmful to students [61]. However, it should not be assumed that students who are multitasking cannot concentrate [62]. According to Prensky [27], digital natives are used to receiving fast information and are good at multitasking (e.g. simultaneously doing homework, using Google, Facebooking friends, listening to music), but these skills received little appreciation from the digital immigrants. Obviously, there is a generation gap between the students and parents or teachers.

\section{Conclusion}

This study was part of a larger project researching how computer games might support mathematics teaching and learning. From this part of the study, all sample groups were found to have a common view that simple and easy mathematics was favorable by students. When students progress to higher grades, they tend to be more negative because mathematics is getting harder and abstract. Apart from that, teachers revealed the students' disinterest in mathematics had led to the culture of learning for the sake of exams. Apparently, this finding has shown that students are lack of motivation to learn mathematics. In this case, the use of computer games could offer an alternative pedagogy to instigate motivation in the students. The students were supportive and positive towards the use of computer games in learning because they wanted to be actively involved and to have fun. Apparently, children live in the present and the instant experience is more important to them. Adults however have a conception of the future. The teachers and parents perceived the use of chalk-and-talk as the best teaching approach. The parents recognized personal 
communication and socialization as a significant component in learning. Apparently, these teachers and parents are dubious about technological use in education.

An obvious gap exists between the emphasis of conservative teachers who presumed chalkand-talk to be the most effective teaching approach, and the technologically savvy students that expected learning to be fun and exciting. Several studies conducted in Malaysia also revealed that students were positive towards the use of computer games in learning [29], [30], [63]-[66]. This study also seems to have exposed to conflict between pro-technology students and the conservative parents, in which they controlled and limited students' access to technology in the cultures and practices at home. The findings of this study coincide with [24], [67] that teachers and parents are reluctant to support digital game-based learning.

The existence of controversy is inevitable in any educational research. It is indeed crucial to provide the best possible outcomes for all the parties concerned. Since students have a strong affinity for computer technologies, computer games could be employed in mathematics education. As recommended by the teachers and parents, digital technologies at best a possible additional complementary feature. In view of that, combination of chalk-and-talk and computer games is alleged to be the best approach to digital game-based learning. The conventional classroom teaching should be retained to deliver the major learning content, and computer games can be employed trivially whenever deemed to be appropriate for the topics learned. Computer games act only as supporting learning tools to complement and enhance the learning processes. It should be noted that computer games should not be adopted blindly into the classroom learning. It defeats the purpose of learning with technology if the existing learning practices (e.g. drill-and-practice) are pushed into the technology as the learning outcomes would be the same. Technology should be used as a means to achieve better educational goals such as constructivism or situated learning. In this instance, the role of teachers should not be diminished and undermined. In the event where the computer facilities are not available in schools, the embodied learning theories of computer games could be employed, and this would be a suggestion for future research. Computer games are embedded with many good learning theories because they are motivating and engaging [68]. Identification of good learning theories (e.g. constructivism, situated learning and experiential learning) in computer games could be used in the mathematics classroom for improvement.

\section{References}

[1] Ke, F., "A case study of computer gaming for math: Engaged learning from gameplay?," Comput. Educ., vol. 51, no. 4, pp. 1609-1620, Dec. 2008. https://doi.org/10.1016/j.compedu.2008.03.003

[2] Ke, F., "A Qualitative Meta-Analysis of Computer Games as Learning Tools," in Handbook of Research on Effective Electronic Gaming in Education, R. Ferdig, Ed. Hershey, PA: Information Science Reference, 2009, pp. 1-32. https://doi.org/10.4018/978-1-59904-808$6 . \operatorname{ch} 001$

[3] Mayer, R., "Cognitive, metacognitive, and motivational aspects of problem solving," Instr. Sci., vol. 26, no. 1, pp. 49-63, 1998. https://doi.org/10.1023/A:1003088013286

[4] McLeod, D. B., "Research on affect in mathematics education: A reconceptualization," in Handbook of research on mathematics teaching and learning: A project of the National Council of Teachers of Mathematics, D. A. Grouws, Ed. New York: MacMillan, 1992, pp. 575-596.

[5] Chamberlin, S. A., "A review of instruments created to assess affect in mathematics," J. Math. Educ., vol. 3, no. 1, pp. 167-182, 2010.

[6] Vale, C. "Trends and factors concerning gender and mathematics in Australasia," in 11th International Congress on Mathematical Education, 2008.

[7] Barkatsas, A., Kasimatis, K., and Gialamas, V., "Learning secondary mathematics with technology: Exploring the complex interrelationship between students' attitudes, engagement, gender and achievement," Comput. Educ., vol. 52, no. 3, pp. 562-570, Apr. 2009. https://doi.org/10.1016/j.compedu.2008.11.001

[8] Artzt, A. F. and Armour-Thomas, E., "Mathematical problem solving in small groups: Exploring the interplay of students' metacognitive behaviors, perceptions, and ability levels," J. Math. Behav., vol. 16, no. 1, pp. 63-74, 1997. https://doi.org/10.1016/S07323123(97)90008-0 
[9] Yaratan, H. and Kasapoğlu, L.,“ Eighth Grade Students' Attitude, Anxiety, and Achievement Pertaining to Mathematics Lessons," Procedia - Soc. Behav. Sci., vol. 46, pp. 162-171, Jan. 2012. https://doi.org/10.1016/j.sbspro.2012.05.087

[10] Marchis, I., "Factors that influence secondary school students' attitude to mathematics," Procedia - Soc. Behav. Sci., vol. 29, no. 1, pp. 786-793, Jan. 2011. https://doi.org/10.1016/j.sbspro.2011.11.306

[11] Pierce, R., Stacey, K., and Barkatsas, A., "A scale for monitoring students' attitudes to learning mathematics with technology," Comput. Educ., vol. 48, no. 2, pp. 285-300, Feb. 2007. https://doi.org/10.1016/j.compedu.2005.01.006

[12] Pea, R., "Cognitive technologies for mathematics education," in Cognitive science and mathematics education, A. H. Schoenfeld, Ed. Hillsdale, NJ: Lawrence Erlbaum Associates Publishers, 1987, pp. 89-122.

[13] Chang, S. H., "Learning mathematics through computer games," in Proceedings of the 14th Asian Technology Conference in Mathematics, 2009, pp. 168-177.

[14] Offenholley, K., "Toward an Analysis of Video Games for Mathematics Education," J. Math. Educ. Teach. Coll., vol. 2, no. 2, pp. 45-48, 2011.

[15] Phaire, C. B., "Video Games and Mathematics Education: Studying Commercial Sports Video Games to Identify the Potential for Learning and Thinking About Mathematics," in Proceedings of the Ninth International Conference Mathematics Education in a Global Community, 2007, pp. 1993-1995.

[16] Prensky, M., "Digital game-based learning," Comput. Entertain., vol. 1, no. 1, p. 21, Oct. 2003. https://doi.org/10.1145/950566.950596

[17] Wishart, J. "Cognitive factors related to user involvement with computers and their effects upon learning from an educational computer game," Comput. Educ., vol. 15, no. 1, pp. 145150, 1990. https://doi.org/10.1016/0360-1315(90)90140-3

[18] Becker, K. "Teaching with games: The Minesweeper and Asteroids experience," J. Comput. Sci. Coll., vol. 17, no. 2, pp. 23-33, 2001.

[19] Rosas, R., Nussbaum, M., Cumsille, P., Marianov, V., Correa, M., Flores, P., Grau, V., Lagos, F., López, X., López, V., Rodriguez, P., and Salinas, M., "Beyond Nintendo: design and assessment of educational video games for first and second grade students," Comput. Educ., vol. 40, no. 1, pp. 71-94, Jan. 2003. https://doi.org/10.1016/S0360-1315(02)00099-4

[20] Mokka, S., Väätänen, A., Heinilä, J., and Välkkynen, P., "Fitness Computer Game with a Bodily User Interface," in Proceedings of the 2nd International Conference on Entertainment Computing, 2003, pp. 1-3.

[21] Natvig, L. and Line, S.,“Age of computers,” ACM SIGCSE Bull., vol. 36, no. 3, pp. 107-111, Sep. 2004. https://doi.org/10.1145/1026487.1008026

[22] Y. Cai, B. Lu, Z. Fan, C. Indhumathi, K. T. Lim, C. W. Chan, Y. Jiang, and L. Li, "Bioedutainment: Learning life science through X gaming," Comput. Graph., vol. 30, no. 1, pp. 39, Feb. 2006. https://doi.org/10.1016/j.cag.2005.10.003

[23]Ebner, M. and Holzinger, A., "Successful implementation of user-centered game based learning in higher education: An example from civil engineering," Comput. Educ., vol. 49, no. 3, pp. 873-890, Nov. 2007. https://doi.org/10.1016/j.compedu.2005.11.026

[24] Becker, K., "Digital game-based learning once removed: Teaching teachers," Br. J. Educ. Technol., vol. 38, no. 3, pp. 478-488, May 2007. https://doi.org/10.1111/j.14678535.2007.00711.x

[25]Zevenbergen, R., "Reforming mathematics education: A case study within the context of new times," in Proceedings of the 26th Annual Conference of the Mathematics Education Research Group of Australasia, 2003.

[26]Zevenbergen, R., "Technologising Numeracy: Intergenerational differences in working mathematically in new times," Educ. Stud. Math. Educ., vol. 56, no. 1, pp. 97-117, 2004. https://doi.org/10.1023/B:EDUC.0000028399.76056.91

[27] Prensky, M., "Digital Natives, Digital Immigrants," Horiz. (MCB Univ. Press., vol. 9, no. 5, pp. 1-6, 2001.

[28] Cheah P. K., and Merican, A. M., "Education Policy: A Case Study of Digitizing Education in Malaysia," Procedia - Soc. Behav. Sci., vol. 69, no. 1, pp. 1714-1718, Dec. 2012. https://doi.org/10.1016/j.sbspro.2012.12.119

[29] Shafie A., and Wan Ahmad, W. F., "Design and Heuristic Evaluation of MathQuest: A RolePlaying Game for Numbers," Procedia - Soc. Behav. Sci., vol. 8, pp. 620-625, Jan. 2010. https://doi.org/10.1016/j.sbspro.2010.12.086 
[30] Latif, R. A., "Understanding Malaysian students as gamers: experience," in Proceedings of the 2nd international conference on Digital interactive media in entertainment and arts - DIMEA '07, 2007, pp. 137-141. https://doi.org/10.1145/1306813.1306843

[31] Johnson B., and Christensen, L. Educational Research Quantitative, Qualitative and Mixed Approaches. Thousand Oaks, CA: Sage Publications, 2008.

[32] Fraenkel, J. R. and Wallen, N. E., How to Design and Evaluate Research in Education, 6th ed. Boston: McGraw-Hill, 2006.

[33] Gall, M. D., Borg, W. R., and Gall, J. P., Educational Research: An introduction, 6th ed. White Plains, New York: Longman Publishers, 1996.

[34] Papalouka, A., "Secondary teachers' understandings of dyslexia in England and Greece," Doctroral Dissertation. University of Nottingham, 2011.

[35] Patton, M. Q., Qualitative Evaluation Methods. Beverly Hills, CA: Sage Publications, 1980.

[36] Cohen, L., Manion, L., and Morrison, K.,Research Methods in Education, 6th ed. New York: Routledge, 2007.

[37] Morse, J. M., “Determining sample size,” Qual. Health Res., vol. 10, no. 1, pp. 3-5, 2000. https://doi.org/10.1177/104973200129118183

[38] Mertens, D. M., Research and Evaluation in Education and Psychology, 3rd ed. United States: Sage Publications, Inc., 2010.

[39] Morse, J., "Designing Funded Qualitative Research,” in Handbook of Qualitative Research, N. K. Denzin and Y. S. Lincoln, Eds. Thousand Oak, CA: Sage Publications, 1994, pp. 220-235.

[40] Creswell, J. W., Qualitative inquiry and research design: Choosing among five traditions. Thousand Oaks, CA: Sage, 1998.

[41] Sandelowski, M., "Sample size in qualitative research," Res. Nurs. Health, vol. 18, no. 2, pp. 179-183, 1995. https://doi.org/10.1002/nur.4770180211

[42] Amoah, S. A., "The reflective and collaborative practices of teachers in Ghanaian basic schools: A case study," Doctoral Dissertation. University of Nottingham, 2011.

[43] Minott, M. A., "Reflection and Reflective Teaching A Case Study of Four Seasoned Teachers in the Cayman Islands," Doctoral Dissertation. University of Nottingham, 2006.

[44] Mason, M., "Sample Size and Saturation in PhD Studies Using Qualitative Interviews," Forum Qual. Sozialforschun/ Forum Qual. Soc. Res., vol. 11, no. 3, 2010.

[45]Elliot A. J., and Harackiewicz, J. M., "Goal setting, achievement orientation, and intrinsic motivation: A mediational analysis.,” J. Pers. Soc. Psychol., vol. 66, no. 5, pp. 968-980, 1994. https://doi.org/10.1037/0022-3514.66.5.968

[46] Awanta, E. K., "Students' Views of Mathematics: A Survey of Junior and Senior High Schools in the Ashanti and Brong Ahafo Regions," Ghana Policy J., vol. 3, pp. 90-109, 2009.

[47] Kislenko, K., "Structuring students' beliefs in mathematics: A Norwegian case," in In Current State of Research on Mathematical Beliefs XII. Proceedings of the MAVI-12 Workshop., 2006, pp. 45-57.

[48] TIMSS, "TIMSS 2011 International Results in Mathematics," 2011. [Online]. Available: http://timssandpirls.bc.edu/timss2011/downloads/T11_IR_Mathematics_FullBook.pdf. [Accessed: 19-Jan-2015].

[49] PISA, "PISA 2012 Results in Focus - What 15-year-olds know and what they can do with what they know," $2012 . \quad$ OECD, Anline]. Available: http://www.oecd.org/pisa/keyfindings/pisa-2012-results-overview.pdf. [Accessed: 19-Jan2015].

[50]Denis G., and Jouvelot, P., "Motivation-driven educational game design: applying best practices to music education," in Proceedings of the 2005 ACM SIGCHI International Conference on Advances in computer entertainment technology - ACE '05, 2005, pp. 462465. https://doi.org/10.1145/1178477.1178581

[51] Witkin, H. A., Moore, C. A., Goodenough, D., and Cox, P. W., "Field-Dependent and FieldIndependent Cognitive Styles and Their Educational Implications,” Rev. Educ. Res., vol. 47, no. 1, pp. 1-64, 1977. https://doi.org/10.3102/00346543047001001

[52] Ke, F., "Computer games application within alternative classroom goal structures: cognitive, metacognitive, and affective evaluation," Educ. Technol. Res. Dev., vol. 56, no. 5, pp. 539556, Jan. 2008. https://doi.org/10.1007/s11423-008-9086-5

[53] Subrahmanyam, K., Greenfield, P., Kraut, R. and Gross, E., "The impact of computer use on children's and adolescents' development," Appl. Dev. Psychol., vol. 22, no. 1, pp. 7-30, 2001. https://doi.org/10.1016/S0193-3973(00)00063-0

[54] Ahuja, M., "Teens are spending more time consuming media on mobile devices," The Washington Post, 14-Mar-2013. 
[55] Zhang, M., "Discovering the unequal interest in popular online educational games and its implications: A case study," Br. J. Educ. Technol., Jan. 2014.

[56] Chao, R., and Tseng, V., "Parenting of Asians," in Handbook of Parenting, Mahwah, NJ: Lawrence Erlbaum Associates, 2002, pp. 59-93.

[57] Perle, E., "5 myths about teens and technology every parent should ignore," Huff Post Parents, 2014. [Online]. Available: http://www.huffingtonpost.com/elizabeth-perle/4-myths-aboutteens-and-t_b_4711061.html. [Accessed: 27-Dec-2014].

[58] McNaught, C., Lam, P. and Ho, A., "The digital divide between university students and teachers in Hong Kong," in Same places, different spaces. Proceedings ASCILITE, 2009.

[59] Prensky, M., "The motivation of gameplay: The real twenty-first century learning revolution," Horiz., vol. 10, no. 1, pp. 5-11, 2002. https://doi.org/10.1108/10748120210431349

[60]Zulkefly S. N., and Baharudin, R., "Mobile Phone use Amongst Students in a University in Malaysia: Its Correlates and Relationship to Psychological Health,” Eur. J. Sci. Res., vol. 27, no. 2, pp. 206-218, 2009.

[61] Paul M., and Gelish, L., "College Students' Texting Habit and Their Academic Performance," in Allied Academies International Conference. Academy of Educational Leadership. Proceedings, 2011, vol. 16, no. 2, pp. 67-72.

[62] Brown, J. S., "Growing Up: Digital: How the Web Changes Work, Education, and the Ways People Learn," Chang. Mag. High. Learn., vol. 32, no. 2, pp. 11-20, 2000. https://doi.org/10.1080/00091380009601719

[63] Wan Ahmad, W. F., Shafie, A. and Abd Latif, M. H. A., "Role-Playing Game-Based Learning in Mathematics," Electron. J. Math. Technol., vol. 4, no. 2, pp. 185-196., 2010.

[64] Shafie, A, and Wan Ahmad, W. F., "Design of the Learning Module for Math Ques: A Role Playing Game for Learning Numbers," in International Conference on Communication Engineering and Networks, 2011, vol. 19, pp. 107-113.

[65] Shafie, A, and Wan Ahmad, W. F., "Designing Role-Playing Games to learn Mathematics," in 16th International Conference on Engineering Education, 2010.

[66] Abdullah, M. R. T. L., Bakar, Z. A. R., Ali, M., Faye, I., Hassan, M. H., bin Amar, A. Z., and Yaacob, R. A. I. R., "Video Games in Children's Learning of Mathematics," Int. J. Basic Appl. Sci., vol. 11, no. 2, pp. 14-17, 2011.

[67] Bourgonjon, J., Valcke, M., Soetaert, R., de Wever, B., and Schellens, T., "Parental acceptance of digital game-based learning," Computers \& Education, Aug-2011. [Online]. Available: http://linkinghub.elsevier.com/retrieve/pii/S036013151100008X. [Accessed: 29Mar-2016].

[68] Gee, J. P., What Video Games Have to Teach Us About Learning and Literacy. England: Palgrave Macmillan, 2007. 